\title{
THE HISTORY OF THE CREATION AND SEMANTICS OF THE SACRED SPACE OF UST-MEDVEDITSKIY CONVENT CAVES IN VOLGOGRAD REGION
}

\author{
Vitaliy V. Stepkin \\ Pavlovsk Secondary School with Enhanced Coverage of Certain Subjects, \\ Pavlovsk, Russian Federation
}

\begin{abstract}
Introduction. The article presents the caves of Ust-Medveditsky St. Saviour convent in Volgograd region. The relevance of the research issue is in improving the recreational potential of the subject under study. The novelty of the work is in explaining the meaning of cave complex elements and the iconic stone with the image of knee and palm prints. The aim of the work is to study the history of creating the sacred space in the caves of Ust-Medveditsky convent. Herewith the work covers the following issues: 1) considering the history of creating caves by hegumeness Arseniya (Sebryakova); 2) clarification of the semantic meaning of some architectural elements in the cave complex in the context of creating the sacred space in the New Jerusalem of the Don region; 3) recommendations for developing the esthetical component of the caves, which increases the recreational potential for using the caves. Methods. In order to achieve the goals the author uses the structuralsemantic method, which allows to reveal the meaning of separate architectural elements in the caves in the structure of the cave complex. The system-based culturological method and the historical archaeological approach are used to understand the uniqueness of the object against the historical background of the dominating culture. The sources used to fulfill the objective include material ones such as architectural elements of the caves, written ones such as piligrimages, travellers' notes about visits to the Holy Land, the biography of hegumeness Arseniya (Sebryakova). Analysis and Results. The caves under consideration were created in the second half of the $19^{\text {th }}$ century by hegumeness Arseniya (Sebryakova). There was a sacred space of the Holy Land reconstructed: "Stations of the Cross" and "Sorrowful Way of the Holy Mother". The stone with the image of knee and palm prints symbolizes the place where the Christ fell down after being arrested. Premise no. 8 with a step can symbolize the Holy Sepulcher with the tomb of Jesus. To improve the recreational potential of UstMedveditsky convent it is necessary to control microclimatic conditions, support the cave surface natural stone relief and colour, decorate the key sacred spaces with thematic icons.

Key words: caves, Russian Orthodox Church, Ust-Medveditskiy St. Saviour convent, hegumeness Arseniya (Sebryakova), Sorrowful Way, Via Dolorosa, the Edicule, New Jerusalem.

Citation. Stepkin V.V. The History of the Creation and Semantics of the Sacred Space of Ust-Medveditskiy Convent Caves in Volgograd Region. Vestnik Volgogradskogo gosudarstvennogo universiteta. Seriya 4. Istoriya. Regionovedenie. Mezhdunarodnye otnosheniya [Science Journal of Volgograd State University. History. Area Studies. International Relations], 2019, vol. 24, no. 3, pp. 58-67. (in Russian). DOI: https://doi.org/10.15688/ ๓. jvolsu4.2019.3.5
\end{abstract}




\title{
ИСТОРИЯ ФОРМИРОВАНИЯ И СЕМАНТИКА САКРАЛЬНОГО ПРОСТРАНСТВА ПЕЩЕР УСТЬ-МЕДВЕДИЦКОГО МОНАСТЫРЯ В ВОЛГОГРАДСКОЙ ОБЛАСТИ
}

\author{
Виталий Викторович Степкин \\ Павловская СОШ с УИОП, г. Павловск, Российская Федерация
}

\begin{abstract}
Аннотация. В статье рассматривается история и семантика пещер Усть-Медведицкого Преображенского монастыря в Волгоградской области. Здесь во второй половине XIX века игуменьей Арсенией (Себряковой) было символически воссоздано сакральное пространство Святой Земли: «Крестный путь Спасителя» и «Страстный путь Божией Матери». В статье делается попытка анализа элементов данной сакрализации пространства с привлечением письменных источников и архитектурных параллелей. При поиске аналогий заимствования рассматривается такой жанр паломнических заметок, как хождения, описывающие наиболее почитаемые объекты поклонения и легенды, с ними связанные. Берется во внимание опыт создания на русской почве Нового Иерусалима под Москвой. Делается вывод, что особо почитаемый в Усть-Медведицком монастыре камень с изображением отпечатков коленей и ладоней есть не что иное, как воспроизведение палестинской святыни с места падения Христа после его ареста. Высказывается предположение об идентификации помещения № 8 с Кувуклией в первоначальном замысле создательницы пещер. Обращается внимание на корреляцию размеров уступа в данном помещении (1,8 м - длина, 0,6 м - ширина, 0,4 м - высота) с размерами и местоположением погребального ложа Гроба Господня. Рассматриваются истоки творческого потенциала игуменьи Арсении (Себряковой) по формированию сакрального пространства: высокий образовательный уровень, широкий кругозор восприятия наземных и подземных святынь (прежде всего Киева) во время паломничеств. Даются рекомендации по увеличению рекреационного потенциала пещер УстьМедведицкого монастыря: контроль за микроклиматом, придание поверхности пещер рельефа и цвета натурального камня, используемого при сооружении станций Пути Скорби в Святой Земле, оформление ключевых сакральных локусов тематическими иконами оптимального размера, не подверженными влиянию повышенной влажности.
\end{abstract}

Ключевые слова: пещеры, Русская православная церковь, Усть-Медведицкий Преображенский монастырь, игуменья Арсения (Себрякова), Путь Скорби, Виа Долороза, Кувуклия, Новый Иерусалим.

Цитирование. Степкин В. В. История формирования и семантика сакрального пространства пещер Усть-Медведицкого монастыря в Волгоградской области // Вестник Волгоградского государственного университета. Серия 4, История. Регионоведение. Международные отношения. -2019. - Т. 24, № 3. - С. 58-67. DOI: https://doi.org/10.15688/jvolsu4.2019.3.5

Введение. Пещеры Усть-Медведицкого Преображенского монастыря являются уникальным объектом историко-культурного наследия Донской земли. Вместе с тем их малая изученность снижает рекреационный потенциал, делая актуальным данное исследование. Его новизна заключается в раскрытии семантики элементов пещерного комплекса и особо почитаемого камня с изображением отпечатков коленей и ладоней.

Целью данной работы является изучение истории формирования и семантики сакрального пространства пещер Усть-Медведицкого Преображенского монастыря Урюпинской епархии, расположенного у г. Сера- фимович Волгоградской области. При этом решаются следующие задачи: 1) рассмотрение истории создания подземелий игуменьей Арсенией (Себряковой); 2) выяснение семантической нагрузки отдельных архитектурных элементов подземного комплекса в контексте создания сакрального пространства донского Нового Иерусалима; 3) составление рекомендаций, направленных на развитие эстетической компоненты пещер, повышающей рекреационный потенциал использования подземелий.

Методы. Для решения поставленных задач автором использовался структурно-семантический метод, способствующий выяв- 
лению семантики отдельных архитектурных элементов пещер в структуре подземного комплекса. Также применялся системно-культурологический и историко-системный подход, позволившие понять уникальность рассматриваемого объекта на историческом фоне доминирующей культуры. Использованные источники для достижения цели: материальные архитектурные элементы пещер, письменные - хождения, записки путешественников о посещении Святой Земли, биография игуменьи Арсении (Себряковой).

В связи с закрытием монастыря в советское время и использованием его территории не по назначению долгое время памятник оставался вне поля зрения исследователей. Лишь в XXI в. начинается целенаправленное изучение пещер. В научном сборнике «Спелеология и спелестология» выходят две публикации, посвященные рассматриваемым подземельям [7; 13]. Данные работы с подробным описанием комплекса позволили автору в 2018 г. приступить к решению поставленных в исследовании задач.

Анализ. Создание пещер на территории Усть-Медведицкого монастыря было начато игуменьей Арсенией (Себряковой) в 1874 году. Общая протяженность пещер, созданных игуменьей и ее ближайшими сподвижницами, составила 77 сажень (164 м). Сооружение данных подземелий опиралось на фундамент развития пещерничества в казачьих землях Усть-Медведицкого округа [13, с. 174-175]. Так, например, иноки Межигорской пустыни, образовавшейся в 1638 г. при слиянии рек Дон и Медведица, «влекомые жаждой еще большего духовного подвига <...> нередко уходили из монастыря, поселялись в пещерах лесных и, пребывая там, вели жизнь затворников в совершенном безмолвии, в полном уединении, углубленные в молитву, отрешаясь в ней от всего земного» [15, с. 57].

Кроме того, Анна Михайловна Себрякова, еще до своего пострига в монашество под именем Арсении, сама осуществляла паломничества в монастыри, связанные с воплощением в жизнь христианской аскетической практики подземножительства. Так, в 1852 г. она отправилась пешком в донской Кременской монастырь, возникновение которого было связано с повествованием о подвизающихся здесь в большой пещере отшельников. В 1853 г. Анна Михайловна отправилась пешком в паломничество в Киев, изобилующий подземными монастырями [12, с. 17-18; 14, с. 169].

Примечательно, что в дальнейшем, уже став игуменьей монастыря, она начнет свой подвиг по строительству пещер 10 июля 1874 г. - в день памяти св. Антония КиевоПечерского [12, с. 50]. Над входом в пещеры она повесит так же, как и при входе в Ближние пещеры, где погребен св. Антоний, изображение Страшного Суда [4, с. 256-257]. Да и сами пещеры, как отмечается в ее житии, «устройством своим напоминали пещеры Киево-Печерской лавры: стены, потолки грунтовые, цементированы, пол кирпичный, тоже залит цементом» $[12$, с. 53]. При этом сравнение планиграфии пещер Усть-Медведицкого монастыря с пещерами Киево-Печерской лавры не выявляет прямых аналогий.

О создании игуменьей Арсенией уникальной структуры сакрального топоса свидетельствуют и письменные источники. Так, в ее жизнеописании отмечается: «Главный ход пещер назван матушкой Арсенией “Крестным путем Спасителя"; здесь по стенам висят иконы с изображением последних дней жизни Иисуса Христа, начиная с моления Спасителя о Чаше в Гефсиманском саду и кончая Голгофой, где в углублении стены Крест с Распятым Спасителем во весь рост и предстоящими Божией Матерью и любимым Его учеником. Другую часть пещер матушка назвала “Страстным путем Божией Матери”, в память страдания Царицы Небесной, которое испытывала Она, спеша к месту казни Своего Божественного Сына. Напротив того места, где изображено падение Спасителя под Крестом, находится икона Божией Матери, именуемая “Семистрельная" или "Симеоново проречение”. Это место изображает собою тот момент, когда Пресвятая Дева, спеша к Своему возлюбленному Сыну и увидя Его падшим под тяжестью Креста, почувствовала, что оружие прошло Ее душу» [12, с. 53].

Перед нами налицо творческая попытка повторения сакрального пространства Святой Земли, воссоздания в пещерах Усть-Медведицкого монастыря подобия Виа Долороза (Пути Скорби, Крестного Пути) - улицы в Иерусалиме, символически отражающей путь 
Иисуса Христа к месту распятия. Посетивший Иерусалим в конце XIX в. протоиерей А. Ковальский отмечал, что до 1860 г. станций, символических остановок на Пути Скорби, было девять. Затем произошло выделение четырнадцати остановок: «Преторий Пилата составляет первую станцию; 2-я стация место бичевания и место, где Спаситель взял Свой Крест, чтобы нести на Голгофу, здесь устроена капелла бичевания: Еcce homo; 3-я станция - место первого падения Спасителя с Крестом; 4-я - место встречи Спасителя с Пречистою Своею Матерью; 5-я - место, откуда Симон Киринейский начал помогать нести Крест; 6-я - дом Вероники. Когда она увидела из окна Спасителя, то, схватив полотенце, выбежала и отерла пот и кровь с Его лика, который отпечатлелся затем на плате. 7-я станция - Спаситель другой раз падает с Крестом. <...> 8-я станция находится за судными воротами, составляющими границу города; здесь был произнесен декрет, осуждающий Его на смерть. 9-я - место третьего падения с Крестом, в двадцати шагах от храма Гроба Господня; 10-я - место, где с Него были сняты одежды и где он был напоен оцтом; 11-я - пригвождение к Кресту; 12-я - где Он вознесен на Крест и умер. 13-я - где Он был принят на руки Иосифа и Никодима; 14-я - место положения во Гроб» [21, с. 222].

К сожалению, не удалось найти полного описания станций Усть-Медведицкого монастыря для сопоставления с описанными Ковальским. Но даже приведенный в жизнеописании игуменьи Арсении фрагмент свидетельствует о наличии расхождений. Так, «Крестный путь Спасителя» в Усть-Медведицком монастыре начинается с «Моления о чаще», а в Иерусалиме - с «Претория Пилата». Данный фактор, наряду с наличием «Страстного пути Божией Матери», свидетельствует о творческом воплощении игуменьей Арсенией в пещерном пространстве иерусалимского сакрального топоса. Она не копирует разрабатываемый с XIV в. францисканцами Путь Скорби в Иерусалиме, а возвращается к истокам раннесредневековой традиции, когда маршрут Виа Долороза был совершенно другим. Начинался он от Гефсимании и шел затем к дому Каифы, Преторию Пилата и далее в направлении Гроба Господня [23, p. 37].
Учитывая отсутствие перед нами полного описания замысла игуменьи Арсении в аутентичных источниках, мы должны понимать условность современной реконструкции Пути Скорби в Усть-Медведецкой обители, где в тематическом расположении икон в узловых фрагментах пещерных лабиринтов читаются следующие остановки: № 1 - Моление о чаще, № 2 - Суд у Каиафа, № 3 - Преторий Пилата, № 4 - Капелла бичевания, № 5 - Место падения Спасителя с Крестом и встречи Его с Пречистою Своею Матерью, № 6 - Голгофа место, где Он вознесен на Крест и умер [7]. Помещение № 7 - трактуется как место Успении Пресвятой Богородицы, помещение № 8 как келья игуменьи Арсении (см. рис. 1).

Сакральной доминантой всего пещерного комплекса является пещерный храм в честь Воздвиженья Креста, сакральной доминантой пещерных лабиринтов - помещение № 8. В этом помещении в настоящее время находится особо почитаемый в монастыре камень с изображением отпечатков коленей и ладоней (см. рис. 2). Эти «отпечатки» приписываются как игуменье Арсении, так и Богородице [3, с. 57; 8; 13, с. 175]. Вместе с тем, учитывая отсутствие описания данного, особо почитаемого в настоящее время, камня в дореволюционной литературе, посвященной истории монастыря, мы можем считать данную семантическую нагрузку проявлением повторной мифологизации. Если говорить о первичной символике вырезанных на камне ладоней и коленей, то ее, несомненно, надо искать в общем контексте сакрализации пещерных лабиринтов Усть-Медведицкого монастыря, подбирая соответствующие аналогии в иерусалимских святынях.

Надо заметить, что на Святой Земле достаточно распространен был культ камней, связанный с евангельскими событиями. Описания путешествий паломников изобилуют сообщениями и легендами о почитаемых камнях. Часто упоминаются следы ног Иисуса Христа, отпечатавшиеся на камне, с которого Он вознесся на небо. «Помимо камней, имевших отношение к земной жизни Иисуса Христа, паломникам показывали камни, связанные с именами ветхозаветных пророков, апостолов и ангелов, сопутствующих Христу в его крестном пути, а также камни, отмечен- 


\section{ОТЕЧЕСТВЕННАЯ ИСТОРИЯ}

ные чудесными знамениями. <..> Сведения о почитаемых камнях стали особенно актуальны при непосредственном моделировании ландшафта Святой Земли, что было воплощено в середине XVII в. в процессе возведения Воскресенского монастыря - Нового Иерусалима. На его территории было помещено несколько камней, сделанных по образцу почитаемых камней Святой земли: камень миропомазания, камень жертвоприношения Авраама, камень-подобие колонны, на которой сидел Христос» [11, с. 137-138]. Подобное воспроизведение одного из почитаемых камней Святой Земли, на наш взгляд, имело место и в Усть-Медведицком монастыре. Но в таком случае о каком камне идет речь?

В книге церковного историка П.И. Савваитова «Сказания о земной жизни Пресвя- той Богородицы...», впервые вышедшей в Петербурге в 1869 г. и пользующейся широкой популярностью, отмечалось: «Преданный в саду Гефсиманском, Иисус поведен был иудеями вдоль потока Кедрского, по направлению к памятнику Авессалома, против которого был мост чрез поток (здесь есть мост и теперь). На этом месте Христос, даровавший еще недавно зрение слепорожденному, получил (по славам предания) первое поругание от ведшей его стражи, и тут же было первое падение Его: отпечатки колен и рук Спасителя остались на береговом камне» [17, с. 334]. Очевидно, что воспроизводя в Усть-Медведицком монастыре Крестный путь Спасителя с Моления о чаше в Гефсиманском саду, игуменья Арсения обозначила копией данного камня первое Его падение. Соответственно,

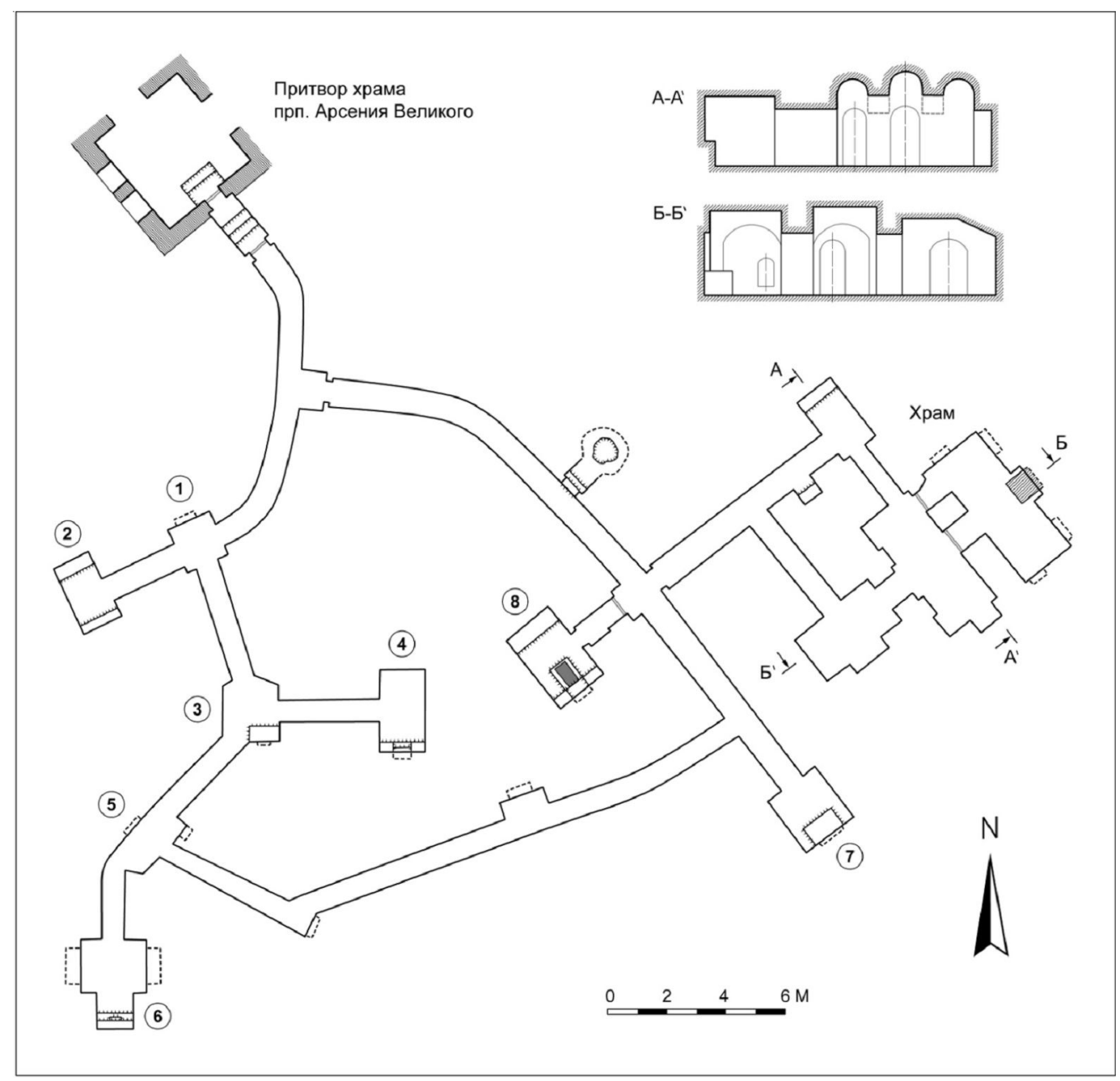

Рис. 1. План пещер Усть-Медведицкого монастыря в Волгоградской области.

Топографическая съемка А.А. Гунько, 2016 г.

Fig. 1. Plan of Ust-Medveditskiy convent caves in Volgograd region.

Topographic mapping by A.A. Gunko, 2016 


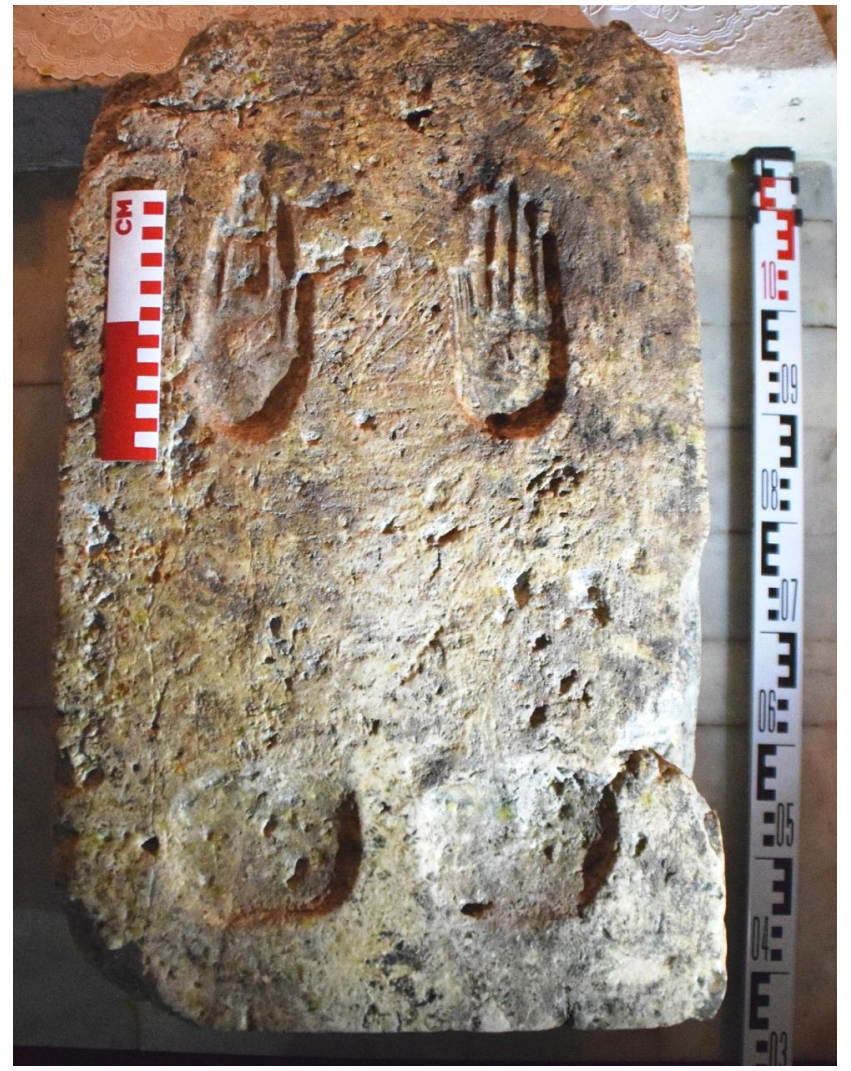

Рис. 2. Камень с изображением отпечатков коленей и ладоней в Усть-Медведицком монастыре Волгоградской области. Фото А.А. Гунько, 2016 г.

Fig. 2. Stone depicting prints of knees and palms in Ust-Medveditskiy convent in Volgograd region. Photo by A.A. Gunko, 2016

расположение данного камня в помещении № 8 в настоящее время следует считать не соответствующим первоначальному замыслу создательницы подземелий. Оно связано, на наш взгляд, с неверной символической трактовкой не только данного камня, но и функционального предназначения помещения при выполнении в пещерах реставрационных работ. Вероятно, отождествив помещение № 8 как келью игуменьи Арсении и посчитав «отпечатки» на камне ей принадлежащими, возрождающие монастырь трудники перенесли камень в данное место.

А каково же было первоначальное предназначение помещения № 8? Для ответа на этот вопрос обратимся прежде всего к его параметрам: ширина 2,9 м, длина 1,8-1,9 м, высота 2,4 м. С правой стороны от входа сделан уступ - 1,8 м длины, 0,6 м ширины, 0,4 м высоты. Выдвигаемая нами гипотеза о функциональном предназначении данного помещения заключается в том, что перед нами не что иное, как Кувуклия, или часовня Гроба Господня. На данную интерпретацию помещения указывает ряд признаков. Во-первых, общая семантика пещерных лабиринтов. В описании Пути Скорби и в католической, и в православной традиции он заканчивается Гробом Господним - главной святыней христианского мира $[16$, с. 70-78; 21, с. 222]. Во-вторых, размеры погребального ложа Гроба Господня коррелируются с размерами уступа в помещении. Мраморная плита, покрывающая Гроб Господень в Иерусалиме, в многочисленных описаниях русских паломников характеризуется размером, имеющим длину 9 пядей и ширину 5 пядей. Об этом мы читаем, в частности, в хождениях XVI в. в Святую Землю Василия Познякова и Трифона Коробейникова, переиздаваемых массовыми тиражами $[10 ; 19 ; 20]$. Если учитывать, что параметры пяди, измеряющей Гроб Господень, колеблются при переводе в метрическую систему в пределах от 19 до 23 см [6], то размеры плиты будут в 
пределах от 1,71 м × 0,95 м до 2,07 м × 1,15 м. Размер поверхности погребального ложа Гроба Господня в Ново-Иерусалимском монастыре под Москвой (построенном по иерусалимскому образцу) составляет «в длину сажень без двух четвертей и без осмушки, в ширину поверх доски полсажени без четверти и без двух осмушек» [9, с. 23]. В переводе в метрическую систему $-1,78$ м × 0,89 м. Если говорить о высоте погребального ложа в иерусалимской Кувуклии, то она, в описаниях путешественников разных эпох, составляет от половины локтя до полутора локтя, что, по всей видимости, связано с реконструктивными работами. При этом размер локтя колебался в диапазоне от 38 до 46 см [6]. Таким образом, размеры уступа в помещение № 8 УстьМедведицкого монастыря $(1,8$ м длины, 0,6 м ширины, 0,4 м высоты) коррелируются с размерами погребального ложа Гроба Господня. При этом меньшие параметры ширины могут объясняться как наличием в прошлом на данном уступе выступающей плиты по образцу Гроба Господня, так и использованием данного пространства в богослужебном процессе в страстную пятницу при выносе и погребении плащаницы [5]. В последнем случае точные размеры погребального ложа имели второстепенное значение по сравнению с символической нагрузкой, как это мы можем наблюдать в приходских храмах. Если говорить о расположении уступа в помещении № 8 УстьМедведицкого монастыря, то он, как и погребальное ложе в иерусалимском Гробе Господнем, располагается с правой стороны от входа, что имеет прообраз в описании евангельских событий: «И, войдя во гроб, увидели юношу, сидящего на правой стороне, облаченного в белую одежду; и ужаснулись. Он же говорит им: не ужасайтесь. Иисуса ищете Назарянина, распятого; Он воскрес, Его нет здесь. Вот место, где Он был положен» (Мк. 16.5).

Если мы будем анализировать параметры не только уступа, но и самого помещения, в котором он располагается, то здесь, надо заметить, мы не наблюдаем корреляции с размерами предполагаемого прототипа - Кувуклии. Можно предположить, что это связано с тем, что при воспроизведении Гроба Господня на русской почве речь не всегда шла о полном копировании пространства Кувуклии. До- статочно было воспроизвести узнаваемую деталь архитектурной композиции, например, погребальную скамью [1]. Это мы и наблюдаем в Усть-Медведицком монастыре в помещении № 8. Говоря о планиграфическом расположении помещения № 8, обратим внимание также на то, что оно располагается к западу относительно пещерного храма, посвященного Кресту. Пещерный иерусалимский храм Обретения Креста, расположенный в самой нижней точке храмового комплекса Воскресения Христова, также находится к востоку от Кувуклии.

Анализируя архитектурные детали помещения № 8 Усть-Медведицкого монастыря и его расположение, мы все же должны заметить, что наша гипотеза о его идентификации с Кувуклией нуждается в подтверждении письменными источниками, учитывая уникальность пещер и отсутствие полных аналогов. Перспективным в этом направлении видится поиск архивных материалов, проливающих дополнительный свет на создание пещерного комплекса и семантическую нагрузку его составляющих.

Говоря в целом о пещерах Усть-Медведицкого монастыря, невозможно не поразиться творческому потенциалу их создательницы. Не случайно об Арсении (Себряковой) одна из светских посетительниц обители сказала следующую фразу: «Ваша матушка поэзия монастыря» [12, с. 64]. Созданные во время ее игуменства как Казанский собор, построенный над пещерами в русско-византийском стиле [18], так и сами пещеры, сочетавшие в себе «Крестный путь Спасителя» и «Страстный путь Божией Матери», не имели аналогов в Области Войска Донского. При этом наземное храмовое пространство отражало восточнохристианскую традицию, а подземное пространство - западную, учитывая перенесение в Россию иерусалимского топоса в рамках вестернизации [2, с. 203]. Развитию творческого потенциала игуменьи Арсении (Себряковой) при создании сакрального пространства Усть-Медведицкого монастыря способствовал заложенный в мирские годы высокий образовательный уровень. К моменту поступления в монастырь она имела обширные познания в сфере литературы, истории и естествознания. Будучи монахиней, она 
постоянно расширяла свой кругозор, читая духовную литературу и осуществляя паломнические поездки в различные уголки России $[15$, c. 94,98$]$.

Результаты. Рассмотрев пещеры, созданные во второй половине XIX в. игуменьей Арсенией (Себряковой), мы выделили на «Крестном пути Спасителя» и «Страстном пути Божией Матери» ключевые локусы сакрального пространства. При этом выдвинутая нами гипотеза о том, что помещение № 8 символизирует Кувуклию, находит подтверждение в параллели уступа у стены с погребальным ложем Гроба Господня. Находящийся в данном помещении камень с изображением отпечатков коленей и ладоней символизирует место падения Христа после его ареста. Этот камень находился ранее в другом помещении.

Проведенный анализ сакрального пространства рассматриваемых пещер показывает их уникальность и значительный рекреационный потенциал. Вместе с тем, на наш взгляд, выполнение определенных работ поможет усилить данную составляющую. Прежде всего речь идет об улучшении микроклимата, понижении влажности в подземельях, что позволит в полной мере осуществлять в пещерном храме регулярное Богослужение. В этом отношении применим опыт сотрудников Национального Киево-Печерского историко-культурного заповедника [22]. Затем возможно придать поверхности Усть-Медведицких пещер цвет и рельеф естественного камня, используемого при сооружении станций Пути Скорби в Святой Земле. Ментальному переносу в сакральное пространство Иерусалима должно способствовать и создание тематических икон оптимальных размеров, выполненных на материале, сохраняющемся долгое время в условиях повышенной влажности. Вместе с тем авторский замысел игуменьи Арсении по семантической нагрузке элементов пещерных лабиринтов должен быть возрожден в полной мере с переносом камня с изображением рук и коленей Христа на соответствующее место.

\section{СПИСОК ЛИТЕРАТУРЫ}

1. Беляев, Л. А. Воспроизведение Гроба Господня / Л.А. Беляев // Православная энциклопе- дия. - Т. XIII. - М. : Церковно-научный центр «Православная энциклопедия», 2006. - С. 138-142.

2. Беляев, Л. А. Иерусалим видимый и невидимый: о типологии визуальных отражений Святой Земли в древнерусской культуре / Л.А. Беляев // Новые Иерусалимы. Иеротопия и иконография сакральных пространств. - М. : Индрик, 2009. C. 202-220.

3. Бородина, Н. Н. Путешествие в древнейшую донскую обитель - Усть-Медведицкий СпасоПреображенский женский монастырь / Н. Н. Бородина // Научно-агрономический журнал. - 2014. T. 1, № 2-1 (95). - C. 56-57.

4. Дятлов, В. А. Киево-Печерская Лавра : справочник-путеводитель / В. А. Дятлов. - Киев : Типография Киево-Печерской Лавры, 2008. - 448 с.

5. Жервэ, А. В. Мера святого Гроба Господня : Традиция перенесения святыни на Руси в XIIXVII вв. / А. В. Жервэ // София. - 2000. - № 4. C. 19-22; 2001. - № 1. - C. 8-12.

6. Каменцева, Е. И. Русская метрология : учеб. пособие / Е. И. Каменцева, Н. В. Устюгов. Изд. 2-е. - М. : Высш. школа, 1975. - 214 с.

7. К изучению пещер Спасо-Преображенского Усть-Медведицкого монастыря / А. А. Гунько, С. К. Кондратьева, В. В. Степкин, А. П. Гунько // Спелеология и спелестология : сб. материалов VIII Междунар. науч. конф. - Набережные Челны : НГПУ, 2017. - С. 151-160.

8. Молчанова, Н. В. Туристско-рекреационный потенциал Волгоградской области / Н. В. Молчанова // Историко-культурное наследие как потенциал развития туристско-рекреационной сферы региона : материалы II Всерос. науч.-практ. конф. Казань : Казанский государственный университет культуры и искусств, 2013. - С. 87-96.

9. Описание соборного храма Воскресения Христова построеннаго по иерусалимскому образцу святейшим патриархом Никоном в Воскресенском Новый Иерусалим именуемом монастыре. М. : Типография В. Готье, $1870 .-86$ c.

10. Перхавко, В. Б. Русские купцы на Святой Земле / В. Б. Перхавко // Вестник церковной истории. - 2016. - № 3-4 (43-44). - С. 284-301.

11. Платонов, Е. В. Почитаемые камни в православной традиции на северо-западе России /Е. В. Платонов // Этнографическое обозрение. 2011. - № 3. - С. 130-144.

12. Подвижницы Усть-Медведицкого монастыря. Игуменья Арсения : Опыт духовной биографии. Письма. - Сарафимович : Издание Усть-Медведицкого монастыря, 2007. - 200 c.

13. Полева, Ю.В.Пещеры игуменьи Арсении Спасо-Преображенского Усть-Медведицкого монастыря / Ю. В. Полева // Спелеология и спелестология : сб. материалов V Междунар. науч. заоч. конф. : 
(К 100-летию А. В. Рюмина). - Набережные Челны : НИСПТР, 2014. - С. 174-178.

14. Попов, Н. Семибратская могила, или Потаенные мощи (В земле Воска Донского) / Н. Попов // Воронежские епархиальные ведомости. - 1868. № 6. - С. 168-172.

15. Правдин, Д. Исторический очерк Усть-Медведицкого Спасо-Преображенского девичьего монастыря Донской области / Д. Правдин. - Ярославль : Тип. губ. правл., 1885. - 196 с.

16. Радзивилл, М. К. Путешествие ко Святым Местам и в Египет князя Николая Христофора Радзивила / М. К. Радзивилл. - СПб., 1787. - 432 с.

17. Савваитов, П. И. Сказания о земной жизни Пресвятой Богородицы с изложением пророчеств и прообразований, относящихся к Ней, учения Церкви о Ней, чудес и чудотворных икон Ея, на основании Священнаго Писания, свидетельств св. Отцев и церковных преданий. Издание восьмое, исправленное и дополненное / П. И. Савваитов. - М. : Издание Русскаго на Афоне Пантелеимонова монастыря, 1904. $-379 \mathrm{c}$.

18. Серебряная, В.В.Культовое зодчество Волгоградской области / В. В. Серебряная. - Волгоград : ВолГАСА, 2002. - $334 \mathrm{c.}$

19. Хождение на Восток гостя Василия Познякова с товарищи (перевод и комментарии О. А. Белобровой) // Повести и сказания Древней Руси : Памятники литературы XI-XVII веков в избранных переводах : Изборник.-СПб. : Диля, 2001.-С. 464487.

20. Хождение Трифона Коробейникова 1593 1594 гг. // Православный Палестинский сборник. T. IX. Выпуск третий. - СПб. : Издание Православного Палестинского Общества, 1889. - 39 с.

21. Шлегель, А. А. Средневековые паломничества к Святой земле в текстах пилигримов / А. А. Шлегель, М. Д. Рукин, И. И. Мазур. - М. : Академия Тринитаризма, 2013. - 308 с.

22. Черевко, I. А. Досліження мікроклімату та інженерно-геологічних умов Ближніх печер з метою визначення оптимальних умов експлуатації та збереження / I. А. Черевко, В. О. Куциба // Дива печер лаврских. - Киів : Національний Києво-Печерський історико-культурний заповідник, 2011. C. 225-237.

23. The Holy Land. Oxford Archaeological Guides / general editor: Barry Cunliffe. - New York : Oxford University Press, 2008. - 551 p.

\section{REFERENCES}

1. Belyaev L.A. Vosproizvedenie Groba Gospodnya [Reproduction of the Holy Sepulchre]. Pravoslavnaya entsiklopediya [Orthodox Encyclopedia]. Moscow, 2006, vol. XIII, pp.138-142.
2. Belyaev L.A. Ierusalim vidimyy i nevidimyy: o tipologii vizualnykh otrazheniy Svyatoy Zemli v drevnerusskoy kulture [Visible and Invisible Jerusalem: on Typology of Visual Reflexions of the Holy Land in the Old Russian Culture]. Novye Ierusalimy. Ierotopiya $i$ ikonografiya sakralnykh prostranstv [New Jerusalems. Hierotopy and Iconography of Sacred Spaces]. Moscow, Indrik Publ., 2009, pp.202-220.

3. Borodina N.N. Puteshestvie v drevneyshuyu donskuyu obitel - Ust-Medveditskiy SpasoPreobrazhenskiy zhenskiy monastyr [Pilgrimage to the Most Ancient Convent on Don - Ust-Medveditskiy St. Saviour Convent]. Nauchno-agronomicheskiy zhurnal, 2014, vol. 1, no. 21 (95), pp. 56-57.

4. Dyatlov V.A. Kievo-Pecherskaya Lavra. Spravochnik-putevoditel [Kiev Pechersk Lavra. A Reference Guide]. Kiev, Tipografiya KievoPecherskoy Lavry, 2008. 448 p.

5. Zherve A.V. Mera svyatogo Groba Gospodnya. Traditsiya pereneseniya svyatyni na Rusi $v$ XII-XVII vv. [Measure of the Holy Sepulcher. Tradition of the Transfer of the Shrine in Russia in the $12^{\text {th }}-17^{\text {th }}$ Centuries]. Sofia, 2000, no. 4, pp. 19-22;2001, no. 1, pp. 8-12.

6. Kamentseva E.I., Ustyugov N.V. Russkaya metrologiya [Russian Metrology]. Moscow, Vysshaya Shkola Publ., 1975. 214 p.

7. Gunko A.A., Kondrateva S.K., Stepkin V.V., Gunko A.P. K izucheniyu peshcher SpasoPreobrazhenskogo Ust-Medveditskogo monastyrya [To the Study of Caves in Ust-Medveditskiy St. Saviour Convent]. Speleologiya i spelestologiya. Sbornik materialov VIII Mezhdunarodnoy nauchnoy konferentsii [Speleology and Spelestology. Proceedings of the 8th International Scientific Conference]. Naberezhnye Chelny, 2017, pp. 151-160.

8. Molchanova N.V. Turistsko-rekreatsionnyy potentsial Volgogradskoy oblasti [Tourist and Recreational Potential of Volgograd Region]. Istoriko-kulturnoe nasledie kak potentsial razvitiya turistskorekreatsionnoy sfery regiona. Materialy II Vserossiyskoy nauchno-prakticheskoy konferentsii [Historical and Cultural Heritage as a Tourist and Recreational Potential of the Region. Materials of the 2nd International Research and Practical Conference]. Kazan, 2013, pp. 87-96.

9. Opisanie sobornogo khrama Voskreseniya Khristova postroennago po ierusalimskomu obraztsu svyateyshim patriarkhom Nikonom v Voskresenskom Novyy Ierusalim imenuemom monastyre [Description of Cathedral Church of the Resurrection Built on the Model of Jerusalem by Patriarch Nikon in Host Resurrection Monastery, Which is Called New Jerusalem]. Moscow, Tipografiya V. Gote, 1870.86 p.

10. Perkhavko V.B. Russkie kuptsy na Svyatoy Zemle [Russian Merchants in the Holy Land]. Vestnik tserkovnoy istorii, 2016, no. 3-4 (43-44), pp. 284-301. 
11. Platonov E.V. Pochitaemye kamni v pravoslavnoy traditsii na severo-zapade Rossii [Venerated Stones in Orthodox Tradition in the NorthWest of Russia]. Etnograficheskoe obozrenie, 2011, no. 3, pp. 130-144.

12. Podvizhnitsy Ust-Medveditskogo monastyrya. Igumenya Arseniya. Opyt dukhovnoy biografii. Pisma. [Ascetics of Ust-Medveditskiy Convent. Hegumeness Arseniya. Experience of Spirit Biography. Letters]. Izdanie Ust-Medveditskogo monastyrya [Periodical of Ust-Medveditskiy Convent]. Serafimovich, 2007. 200 p.

13. Poleva Yu.V. Peshchery igumeni Arsenii SpasoPreobrazhenskogo Ust-Medveditskogo monastyrya [Hegumeness Arseniya's Caves of Ust-Medveditskiy St. Saviour Convent]. Speleologiya i spelestologiya: sbornik materialov V Mezhdunarodnoy nauchnoy zaochnoy konferentsii (K 100-letiyu A.V. Ryumina) [Speleology and Spelestology. Proceedings of the $5^{\text {th }}$ International Scientific Distance Conference (In Celebration of $100^{\text {th }}$ Anniversary of A.V. Ryumin)]. Naberezhnye Chelny, 2014, pp. 174-178.

14. Popov N. Semibratskaya mogila ili potaennye moshchi (V zemle Voyska Donskogo) [Semibratskaya Tomb or Secreted Remains (In the Land of the Don Cossack Host)]. Voronezhskie eparkhialnye vedomosti, 1868, no. 6, pp. 168-172.

15. Pravdin D. Istoricheskiy ocherk UstMedveditskogo Spaso-Preobrazhenskogo devichego monastyrya Donskoy oblasti [Historical Sketch of UstMedveditskiy St. Saviour Convent of the Don Region]. Yaroslavl, 1885. 196 p.

16. Radzivill M.K. Puteshestvie ko Svyatym Mestam $i$ v Egipet knyazya Nikolaya Khristofora Radzivila [Pilgrimage of Knyaz Nikolay Khristofor Radzivil to Holy Places and to Egypt]. Saint Petersburg, 1787. $432 \mathrm{p}$.

17. Savvaitov P.I. Skazaniya o zemnoy zhizni Presvyatoy Bogoroditsy s izlozheniem prorochestv i proobrazovaniy, otnosyashchikhsya k Ney, ucheniya Tserkvi o Ney, chudes i chudotvornykh ikon Eya, na osnovanii Svyashchennago Pisaniya, svidetelstv sv. Ottsev i tserkovnykh predaniy [Legends of Life in This World of the Most Holy Mother of God with Retelling of Her Prophecies and Transformations, Church Teaching About Her, Her Miracles and Wonderworking Icons Based on Holy Bible, Evidences of Holy Fathers and Church Legends]. Izdanie Russkago na Afone Panteleymonova monastyrya. Moscow, 1904. 379 p.

18. Serebryanaya V.V. Kultovoe zodchestvo Volgogradskoy oblasti [Cult Art of Building in Volgograd Region]. Volgograd, 2002. 334 p.

19. Khozhdenie na Vostok gostya Vasiliya Poznyakova s tovarishchi [Piligrimage to the East of Guest Vasiliy Pozdnyakov with Partners]. Povesti i skazaniya Drevney Rusi. Pamyatniki literatury XI-XVII vekov v izbrannykh perevodakh. Izbornik [Stories and Legends ofAncient Rus. Literary Classic of the $11^{\text {th }}-17^{\text {th }}$ Centuries in Selected Translations. Anthology]. Saint Petersburg, Dilya Publ., 2001, pp. 464-487.

20. Khozhdenie Trifona Korobeynikova 15931594 gg. [Pilgrimage of Trifon Korobeynikov in 1593-1594]. Pravoslavnyy Palestinskiy sbornik [Orthodox Palestinian Book]. Saint Petersburg, Izdanie Pravoslavnogo Palestinskogo Obshchestva, 1889, vol. 9, iss. 3. 39 p. 21. Shlegel A.A., Rukin M.D., Mazur I.I. Srednevekovye palomnichestva $k$ Svyatoy zemle $v$ tekstakh piligrimov [Medieval Pilgrimages to the Holy Land in Texts of Pilgrims]. Moscow, Akademiya Trinitarizma, 2013. 308 p.

22. Cherevko I.A., Kutsiba V.O. Doslizhennya mikroklimatu ta inzhenerno-geologichnih umov Blizhnih pecher z metoyu viznachennya optimalnih umov ekspluatacii ta zberezhennya [Microclimatic and Geological Engineering Conditions Control in the Close Caves to Define Optimal Conditions for Their Use and Keeping]. Kiev, 2011, pp. 225-237.

23. Barry Cunliffe, ed. The Holy Land. Oxford Archaeological Guides. New York, Oxford University Press, 2008. $551 \mathrm{p}$.

\section{Information about the Author}

Vitaliy V. Stepkin, Candidate of Sciences (History), History Teacher, Pavlovsk Secondary School with Enhanced Coverage of Certain Subjects, Prosp. Revolutsii, 15, 396420 Pavlovsk, Russian Federation, archeolog@mail.ru, https://orcid.org/0000-0002-7182-5830

\section{Информация об авторе}

Виталий Викторович Степкин, кандидат исторических наук, учитель истории, Павловская СОШ с УИОП, просп. Революции, 15, 396420 г. Павловск, Российская Федерация, archeolog@mail.ru, https://orcid.org/0000-0002-7182-5830 